\title{
Risk Factors for Breast Cancer and Cervical Cancer in PKK Women's Focus Group Discussion (FGD) Member in Salatiga Indonesia
}

\author{
Jodelin Muninggar $^{1}$, Arianti Ina Hunga ${ }^{2}$ \\ \{jodelin.muninggar@staff.uksw.edu ${ }^{1}$,inahunga@gmail.com ${ }^{2}$ \} \\ Research Center of Gender and Childcare, Universitas Kristen Satya Wacana ${ }^{1,2}$
}

\begin{abstract}
In Indonesia, breast cancer and cervical cancer are the main causes of death for women, which is the interaction of genetics and environment. The PKK community is a forum for sharing information about women's reproductive organs, in a Focus Group Discussion (FGD). The aim of the study was to identify the role of the PKK FGD in monitoring the cancer risk factors of its members. The 19 questions breast cancer risk factor questionnaire and 11 cervical cancer questions. Identification in 7 urban villages from August 2016 to January 2017, to 95 members. Results, risk factors for nonmodified cervical cancer: age of marriage $>12$ years, age $>30$ years, number of children $>2$. While the risk factors can be modified: have not been immunized with HPV, have never had a Pap smear, use an IUD contraceptive device. Members are included in the moderate categorywith a score of 4-8 were 42 people (44.21\%). Risk factors for nonmodified breast cancer: age $<12$ years menarche, age of menopause $>55$ years, history of tumors, baby delivery age $>30$ years. Risk factors can be modified: high fat consumption, rarely consume vegetables/fruit, rarely exercise, obesity, radiation exposure. Members are included in the moderate categorywith a score of 5-8 totaling 46 people (48.42\%). Recommendations, consistent health education interventions and high commitment from members for healthy lifestyle changes. Through monitoring the PKK FGD, the commitment to minimize risk factors is maintained.
\end{abstract}

Keywords: cancer, risk factor, FGD, healthy lifestyle, health education.

\section{Introduction}

Cancer is one of public health problems in the world. It can attack various tissues in human's body organs, including female reproductive organs namely cervix and breast. Despite various attempt to prevent this, the morbidity and mortality rate of cervical cancer have not shown any significant decrease [1]. WHO data in 2010 found that there were 7.9 million deaths from cancer in 2007 and predicted that it will increase by $45 \%$ to 11.5 million in 2030 . A total of 11.3 million new cancer cases in 2007 were estimated to increase to 15.5 million in 2030. Cancer prevalence from 1.4 percent to 1.8 percent in 2018 with the highest prevalence in DI Yogyakarta Province [2].

A risk factor is anything that changes your chance of getting a disease such as cancer. Different cancers have different risk factors. Several risk factors increase your chance of developing cervical cancer. Women without any of these risk factors rarely develop cervical cancer. Although these risk factors increase the odds of developing cervical cancer, many 
women with these risks do not develop this disease. When a woman develops cervical cancer or pre-cancerous changes, it might not be possible to say that a particular risk factor was the cause. In thinking about risk factors, it helps to focus on those you can change or avoid (like smoking or human papillomavirus infection), rather than those you cannot (such as your age and family history). However, it is still important to know about risk factors that cannot be changed, because it's even more important for women who have these factors to get regular Pap tests to detect cervical cancer early [3].

Various causes of cervical and breast cancer cannot be separated from the interaction of genetic factors and environmental factors [4]. Every woman carries a risk factor in accordance with her life and, commonly, she does not know how much these risk factors have affected it. Women with high risk factors have a greater chance of developing breast cancer and cervical cancer if compared to women with low risk factors. Therefore, preventive attempts are needed to help women understand the risk factors for breast cancer and cervical cancer [3].

Women's community plays important role as an interacting forum to share various information specifically on the health of women's reproductive organs [5]. Indonesia has a community for women called PKK (Pemberdayaan Kesejahteraan Keluarga or Family Welfare Empowerment), which are still active and can be classified as Focus Group Discussions (FGD) that discusses matters related to family welfare, including women's welfare [6]. In this case, PKK FGD can play a role in identifying and monitoring its members regarding early risk factors for cervical cancer and breast cancer.

\section{Research Methodology}

The research locations were seven administrative villages of KotaSalatiga during August 2016 - January 2017. They includedkelurahan Sidorejo Lor, kelurahan Dukuh, kelurahan Blotongan, kelurahan Kutowinangun Kidul, kelurahan Kutowinangun Lor, kelurahan Gendongan dan kelurahan Kecandran. The selection of these research locations was that they represent the residents of urban areas and the outskirts of Salatiga. The sample was taken by the active board members of PKK who were present at the time of data collection, as many as 95 people.

Data collection was done using a closed questionnaire, in the form of 19 questions of breast cancer risk factors and 11 questions of cervical cancer. The members of PKK FGD or the respondents filled out their identity and answered the questions by giving score 1 if the correct statement matches the situation and scores 0 if the statement does not match the situation. After filling out the questionnaire, each PKK FGD member would have their respective scores to be grouped into low category (1-6), moderate (7-12) and high (13-19) for breast cancer; andlow (1-3), moderate (4-6) and high (7-11) for cervical cancer. The results of this grouping are compared to other PKK members in urban and suburban areas.

\section{Results And Discussion}

Research conducted in seven PKK FGD groups of Kelurahan found that the risk factors for both cervical cancer and breast cancer varied. The non-modified risk factor for cervical cancer among FGD members includeage at first marriage <12 years, age $>30$ years, and number of children $>2$ people. While the modified risk factors include not yet immunized with 
HPV vaccine, never had Pap smear test, and the use of IUD contraceptive device. The highest score earned by the FGD members was 8 . There were 42 people $(44.21 \%)$ of FGD members who scored 4-8. While in the community, the highest risk factor proportionsare age $>30$ years, more than two children, the use of IUD contraception, not yet immunized with HPV vaccine, and never had Pap smear test.

Table 1. The Average Number of Cervical Cancer Risk Respondents in All FGD Groups.

\begin{tabular}{|clcccccccc|}
\hline No & \multicolumn{1}{c}{ Risk Factors } & $\begin{array}{c}\text { Gen- } \\
\text { dongan }\end{array}$ & $\begin{array}{c}\text { Kuto- } \\
\text { Lor }\end{array}$ & Dukuh & $\begin{array}{c}\text { Kuto- } \\
\text { Kdl }\end{array}$ & $\begin{array}{c}\text { Blo- } \\
\text { tongan }\end{array}$ & $\begin{array}{c}\text { Sido- } \\
\text { Lor }\end{array}$ & $\begin{array}{c}\text { Kecan- } \\
\text { dran }\end{array}$ & Avg \\
\hline 1 & $\begin{array}{l}\text { Age at marriage } \\
\text { <12 year }\end{array}$ & 2 & 3 & 7 & 1 & 3 & 8 & 4 & 4 \\
\hline 2 & $\begin{array}{l}\text { Current age> } 30 \\
\text { year }\end{array}$ & 3 & 8 & 11 & 16 & 19 & 22 & 12 & 13 \\
\hline 3 & $\begin{array}{l}\text { Number of } \\
\text { children>2 }\end{array}$ & 2 & 4 & 5 & 6 & 6 & 8 & 3 & 4.9 \\
\hline 4 & Married status>1x & 0 & 1 & 0 & 2 & 0 & 3 & 1 & 1 \\
\hline 5 & $\begin{array}{l}\text { Changes of sexual } \\
\text { partner(s) }\end{array}$ & 0 & 0 & 0 & 0 & 0 & 0 & 0 & 0 \\
\hline 6 & $\begin{array}{l}\text { Birth control } \\
\text { pills }>4 \text { year }\end{array}$ & 0 & 1 & 2 & 2 & 4 & 2 & 2 & 1.9 \\
\hline 7 & $\begin{array}{l}\text { IUD contraceptive } \\
\text { tool }\end{array}$ & 1 & 0 & 1 & 3 & 8 & 8 & 3 & 3.4 \\
\hline 8 & $\begin{array}{l}\text { History of genital } \\
\text { infection/disorder }\end{array}$ & 0 & 0 & 1 & 2 & 3 & 3 & 1 & 1.4 \\
\hline 9 & $\begin{array}{l}\text { History of HPV } \\
\text { infection }\end{array}$ & 0 & 0 & 0 & 0 & 0 & 1 & 0 & 0.1 \\
\hline 10 & $\begin{array}{l}\text { Not yet immunized } \\
\text { with HPV }\end{array}$ & 1 & 4 & 6 & 16 & 9 & 17 & 6 & 8.4 \\
\hline 11 & $\begin{array}{l}\text { Never had pap } \\
\text { smear test }\end{array}$ & 1 & 4 & 4 & 10 & 16 & 10 & 8 & 7.6 \\
\hline
\end{tabular}

Likewise, the risk factors for breast cancer vary in all Kelurahan. The non-modified risk factors include the age of first menstrual period <12 years, age of menopause $>55$ years, history of tumors and age at first birth> 30 years. The modifiable risk factors are high fat consumption, rarely consuming vegetables and fruits, minimum physical exercise, obesity, and radiation exposure. The highest score was 8 . There were 46 people $(48.42 \%)$ of FGD members who had score of 5-8. Whereas in the community, the risk factors with high proportion include high fat consumption, minimum physical exercise, BSE/MAMOGRAPHY examination, radiation exposure and obesity.

Table 2.The Average Number of Breast Cancer Risk Respondents in All FGD Groups.

\begin{tabular}{|llcccccccc|}
\hline No & \multicolumn{1}{c}{ Risk factor } & $\begin{array}{c}\text { Gen- } \\
\text { dongan }\end{array}$ & $\begin{array}{c}\text { Kuto- } \\
\text { Lor }\end{array}$ & Dukuh & $\begin{array}{c}\text { Kuto- } \\
\text { Kdl }\end{array}$ & $\begin{array}{c}\text { Blo- } \\
\text { tongan }\end{array}$ & $\begin{array}{c}\text { Sido- } \\
\text { Lor }\end{array}$ & $\begin{array}{c}\text { Kecan- } \\
\text { dran }\end{array}$ & Avg \\
\hline $\begin{array}{l}\text { Menarche age }<12 \\
\text { year }\end{array}$ & 2 & 3 & 1 & 1 & 5 & 1 & 1 & 2 \\
\hline 2 & Menopause age $>55$ & 2 & 3 & 0 & 3 & 4 & 7 & 0 & 2.7 \\
\hline
\end{tabular}




\begin{tabular}{|c|c|c|c|c|c|c|c|c|c|}
\hline & year & & & & & & & & \\
\hline 3 & Not married & 0 & 0 & 0 & 0 & 0 & 0 & 0 & 0 \\
\hline 4 & $\begin{array}{l}\text { Age of first } \\
\text { birth>30 year }\end{array}$ & 1 & 2 & 3 & 1 & 6 & 4 & 2 & 2.7 \\
\hline 5 & $\begin{array}{l}\text { Abortion with the } \\
\text { age of fetus }>10 \\
\text { weeks }\end{array}$ & 0 & 0 & 1 & 3 & 1 & 0 & 1 & 0.9 \\
\hline 6 & $\begin{array}{l}\text { Breastfeeding } \\
\text { period }<5 \text { months }\end{array}$ & 0 & 1 & 2 & 3 & 4 & 3 & 1 & 2 \\
\hline 7 & $\begin{array}{l}\text { Birth control } \\
\text { pills }>10 \text { years }\end{array}$ & 0 & 0 & 0 & 2 & 1 & 0 & 0 & 0.4 \\
\hline 8 & $\begin{array}{l}\text { High fat } \\
\text { consumption }\end{array}$ & 1 & 6 & 9 & 12 & 12 & 11 & 10 & 8.7 \\
\hline 9 & $\begin{array}{l}\text { Rare consumption } \\
\text { of vegetables and } \\
\text { fruits }\end{array}$ & 2 & 4 & 1 & 3 & 3 & 5 & 3 & 3 \\
\hline 10 & $\begin{array}{l}\text { Alcohol } \\
\text { consumption }\end{array}$ & 0 & 2 & 0 & 0 & 0 & 0 & 0 & 0.3 \\
\hline 11 & $\begin{array}{l}\text { Exposure to } \\
\text { cigarette smoke }\end{array}$ & 0 & 2 & 0 & 1 & 0 & 0 & 0 & 0.4 \\
\hline 12 & $\begin{array}{l}\text { Minimum physical } \\
\text { exercise }\end{array}$ & 1 & 3 & 7 & 6 & 9 & 9 & 9 & 6.3 \\
\hline 13 & Intensivestress & 0 & 0 & 2 & 2 & 4 & 3 & 0 & 1.6 \\
\hline 14 & $\begin{array}{l}\text { Family history of } \\
\text { breast cancer }\end{array}$ & 1 & 0 & 0 & 1 & 4 & 1 & 0 & 1 \\
\hline 15 & History of tumor & 2 & 2 & 2 & 4 & 4 & 3 & 0 & 2.4 \\
\hline 16 & $\begin{array}{l}\text { Never had } \\
\text { BSE/Mammography }\end{array}$ & 1 & 2 & 3 & 4 & 4 & 5 & 5 & 3.4 \\
\hline 17 & $\begin{array}{l}\text { Estrogen hormone } \\
\text { therapy }\end{array}$ & 0 & 0 & 0 & 0 & 1 & 3 & 0 & 0.6 \\
\hline 18 & Radiation exposure & 2 & 0 & 4 & 3 & 6 & 8 & 5 & 4 \\
\hline 19 & Obesity/BMI> 25 & 2 & 2 & 7 & 5 & 6 & 7 & 6 & 5 \\
\hline
\end{tabular}

By looking at the questionnaire result, the risk factors for cervical cancer and breast cancer of PKK FGD group member of Kota Salatiga who are at risk was in medium category. By referring to the risk factors possessed by FGD members, it is necessary to carry out interventions to change their lifestyle, especially for modifiable risk factors. Each Kelurahan has different risk factors, so the intervention is adjusted to the risk factors possessed by each member of the FGD [7]. This process requires consistency and commitment from each FGD member. This FGD group is needed for the members to monitor each other.

Therefore, the next step of this research was to organize health education in order to motivate the FGD members to change their lifestyle in relation to the modifiable risk factors. The unmodified risk factors for cervical cancer include age at marriage <12 years, age $>30$ years, and number of children> 2 people. On the other hand, the modifiable risk factors 
include never had HPV immunization, never had Pap smear test, and the use of IUD contraceptive device.

The FGD members who were 55-65 years old had unmodified risk factor for cervical cancer, which included marriage age $<12$ years, hadmore than 2 children, and were currently $>$ 30 years old. These risk factors cannot be avoided and changed because it is a life process that has passed and becomespart of their history. In different studies on breast cancer and cervical cancer found that the most notable breast and cervical cancer risk factors as low education levels, high number of deliveries, short breastfeeding period, obesity and low socio-economic level [7].

On the other hand, the modifiable risk factors include never had HPV (Human Papilloma Virus) immunization, and never experienced Pap smear test. Therefore, the FGD members had to receive immunization and do Pap smear test. However, there was no obligation to receive HPV immunization to prevent cervical cancer for married women and their age already passed their reproductive age. This is different from adolescents between the ages of 15-17 years old who have never had sexual contact, HPV vaccination serves as a preventive effort on cervical cancer [8]. Furthermore, Pap smeartest provides the benefits of early detection of cellular abnormalities that could initiate cervical cancer. This is supported by a research [9] who found that that there was a correlation between early detection of pap smears and the incidence of cervical cancer in EFA aged 20-35 years at Onkologi RSUD Dr.Soegiri Lamongan. Thus, a follow-up preventive act for FGD members in Kelurahan Gendongan was a Pap smear examination by facilitating the nearest clinical laboratory in Salatiga, through a routine program in collaboration with BPJS. The Community Service Team could help facilitate getting the HPV vaccine from distributors so that they could reduce the price of HPV vaccines to be more affordable for more people. Thus, the team could truly help the FGD members in the implementation of preventive measures.

The use of IUD contraceptives in the uterus causes friction between the thread and the cervix which occurs continuously for several years. Presumably, it can cause chronic irritation and inflammation, which could also cause a cell change towards malignancy [3]. From a number of studies abroad, there were infections and cytological changes in IUD users, even though it was not significant. The team provides clear explanation about the risk effects so that the user can properly understand and will be responsible for their decisions.

Furthermore, the unmodifiable risk factors for breast cancer include menstrual age $<12$ years, age of menopause $>55$ years, and history of tumors. Therisk factor of age cannot be changed, so no attempt is made to change it. Women with a history of tumors or cancers in their reproductive organs such as the ovary, are more likely to get breast cancer. Women with breast cancer show ovarian cortex hyperplasia. The increased risk of breast cancer in women with tumors or ovarian cancer is thought to be related to the effect of an increase in estrogen hormone [10]. For this reason, the FGD members need to be motivated to observe their history of family disease and be aware of this factor.

Whereas, the modifiable risk factors are rare consumption of vegetables and fruits, high fat consumption, minimum physical exercise, radiation exposure, obesity, and self-breast examination (SBE) and clinical breast examination (CBE) $[3,7]$.

Rare consumption of vegetables and fruits containing dietary fiber will slow the transit time of digestible food in the intestine, so that it triggers initiation process or mutation of genetic material in the cell nucleus. Vegetables and fruits contain anti-carcinogenic substances such as carotenoids, selenium and tocopherol, which can reduce the influence of outside materials and provide an environment that will suppress the development of abnormal cells. Similarly, high fat consumption in everyday life will increase the risk of breast cancer due to 
the increased formation of fat tissue and increased estrogen production. Increasing the concentration of estrogen in the blood will increase the proliferative effects of estrogen on the ductal epithelium of the breast and breast cancer. Therefore, it is necessary to continue to strive for a healthy diet every day [11].

Low physical activity will cause an imbalance of intake and outtake calories. Moderate physical activity will reduce the risk of breast cancer and affect the decrease in hormonal circulation and reduce the proliferation process and prevent the occurrence of breast cancer. Women who do regular physical activity for a long time will reduce the risk of breast cancer by $37 \%$. Therefore, the Team provided health education regarding healthy food and energy need, so that it will change the understanding and consumption patterns. The next thing is to facilitate the existence of physical activities such as routine gymnastics in the community and will be continued in their families regularly [12].

Associated with obesity risk factors as indicated by Body Mass Index (BMI) $>25$, there is an increased risk of breast cancer in women. This is due to the increase of estrogen synthesis in fat deposits which has an effect on the breast tissue proliferation process. Periodic calculation of BMI is mandatory as a control of body weight and dietary intervention (13).

Radiation exposure to body cells causes a buildup of energy in the material it passed. Even though the energy accumulated by radioactive rays on living things is relatively small, it can cause serious effects. This is because radioactive rays can cause ionization, breaking important chemical bonds or forming reactive free radicals. Important chemical bonds can also include the bonds in the DNA structure in chromosomes. Changes occurring in the DNA structure will be forwarded to the next cell which can lead to genetic abnormalities and cancer. The effect of radiation on humans or living things also depends on the time of exposure. A dose received at one exposure will be more dangerous than if the same dose is received at a longer period of time. We naturally receive radiation from the environment, such as cosmic ray radiation or radiation from natural radioactive. Furthermore, we can also receive radiation from various activities such as diagnosis or therapy by using X-ray or radioisotopes. People who live around nuclear installations also receive more radiation, but are still within safe limits. The exposure to radiation for diagnosis or therapy should be avoided if possible, unless there is no other way for health treatment that must be taken [12].

Self-breast examination (BSE) is a mandatory act for every FGD member every month after menstruation period ends. Examination after menstruation is carried out due to minimal hormonal influence on breast tissue so that the examination would be more flexible and more accurate. This demo about SBE can be done using phantom breast [14] .

Consistent effort and high commitment from each FGD member is required to make changes of healthy lifestyle regarding the modifiable risk factors in each kelurahan. PKK FGD of each kelurahan continues to carry out its functions in monitoring the development of the risk factors of its members. By monitoring the early risk factors for cervical cancer and breast cancer in women in Salatiga, especially the FGD members, there would be an awareness among the FGD members to change the negative risk factors for breast cancer and cervical cancer into a healthier lifestyle [15].

The implementation of health education by the Community Service Team should be continued and carried out by each member of PKK FGD to other community members and their family members. Reminding each otheris a preventive act that must always be emphasized and reminded to form a healthy lifestyle, which could minimize the risk and potential factors affected by both cancers. Therefore, this can reduce the rate of maternal morbidity and mortality [16]. 


\section{Conclusion}

Medium risk factors for breast cancer and cervical cancer increase awareness for women, health workers and related health institutions. Risk factors for breast cancer and cervical cancer have been identified among 95 members of PKK of seven villages in Kota Salatiga during August 2016 to January 2017. The results show that the non-modified risk factors for cervical cancer include age of marriage $>12$ years, age $>30$ years, number of children> 2 people; while the modified risk factors include not immunized with HPV, never had Pap smear test, and the use of IUD contraceptive device. There are 42 members $(44.21 \%)$ with medium risk factors, scoring 4-8. The non-modified risk factors for breast cancer includemenarche age $<12$ years, menopause age $>55$ years, history of tumors, delivery age > 30 years. Modified risk factors include high fat consumption, rarely consuming vegetables/fruits, rarely exercise, obesity, and radiation exposure. The members with moderate risk category are 46 people $(48.42 \%)$, scoring $5-8$. PKK as FGD can be used as a forum to identify and monitor the progress of risk factors for these cancers.

\section{References}

[1]Adiyono W, Amarwati S, Nurkukuh, Suhartono. 2007. Hubungan hasil pap-smear dengan hasil pemeriksaan kolposkopi pada skrining lesi serviks. Media Medika Indonesiana. 42(2): 77-8.

[2]Rossa V. And Nodia F. Hasil Riskesdas 2018, Penyakit Tidak Menular Semakin Meningkat. 2018. https://www.suara.com/health/2018/11/02/101437/hasil-riskesdas-2018penyakit-tidak-menular-semakin-meningkat.

[3]American camcer Society. 2017. https://www.cancer.org/cancer/cervical-cancer/causesrisks-prevention/risk-factors.html.

[4]Parsa N. Environmental Factors Inducing Human Cancers. Iran J Public Health. 2012; 41(11): 1-9.

[5]Lupton D. And Maslen S. 2019. How Women Use Digital Technologies for Health: Qualitative Interview and Focus Group Study. J Med Internet Res. 2019; 21(1): e11481. https://www.ncbi.nlm.nih.gov/pmc/articles/PMC6367665/

[6]Morton, Pakudek, Wangka W.M. Susana B.O.L. Peran Lembaga Pemberdayaan Kesejahteraan Keluarga (PKK) dalam Peningkatan Kapasitas Perempuan Desa Sea Kecamatan Pineleng Kabupaten Minahasa. Agri - Sosioekonomi. 2018; 14(3). https://ejournal.unsrat.ac.id/index.php/jisep/article/view/22222

[7]Karadag A.S., Bakan A.B., Aslan G. Distribution of cervical and breast cancer risk factors in women and their screening behaviours. Eur J Cancer Care (Engl). 2019; 28(2):e12960. doi: 10.1111/ecc. 12960.

[8]Setyarini, E. Faktor-faktor yang Berhubungan Dengan Kejadian Kanker Leher Rahim Di RSUD Dr. Moewardi Surakarta. Skripsi. Jurusan Kesehatan Masyarakat Universitas Muhammadiyah Surakarta, Surakarta. 2012.

[9]Rasjidi M. Manual prakanker serviks: kanker serviks. Edisi 1. Jakarta : CV Sagung Seto; 2008; pp: 7-10.

[10]Petrucelli N., Daly M.B., Feldman G.1. Hereditary breast and ovarian cancer due to mutations in BRCA1 and BRCA2. Genetics IN Medicine; 2010; 12(5). 
[11]Aghajanpour M., Nazer M.R., Obeidavi Z., Akbari M., Ezati P. and Nasroallah Moradi Kor. Functional foods and their role in cancer prevention and health promotion: a comprehensive review. Am J Cancer Res. 2017; 7(4): 740-769.

[12]Center for Disease Control and Prevention. What Are the Risk Factors for Breast Cancer? 2018. https://www.cdc.gov/cancer/breast/basic_info/risk_factors.htm

[13] Cleary M.P. and Grossmann m.E. Obesity and Breast Cancer: The Estrogen Connection. Endocrinology. 2009; 150(6): 2537-2542. Doi: 10.1210/en.2009-0070.

https:/www.ncbi.nlm.nih.gov/pmc/articles/PMC2689796/

[14]S elf Breast Exam - Your How to Guide.

https://thewomenswellnesscollective.com/journal/2019/3/9/self-breast-exam-your-how-to-

guide

[15]Fatwa Sari Tetra Dewi. Working with community Exploring community empowerment to support non-communicable disease prevention in a middle-income country. 2013. Umea University Medical Dissertations New Series No 1539, ISSN 0346-6612, ISBN 978-91-7459532-1.

[16]Atlan, Human of data. How to Conduct a Successful Focus Group Discussion. 2017. https://humansofdata.atlan.com/2017/09/conduct-successful-focus-group-discussion/ 